Çankırı Karatekin Üniversitesi

İktisadi ve İdari Bilimler

Fakültesi Dergisi

Y. 2018, Cilt 8, Say1 2, ss. 331-354
Cankırı Karatekin University

Journal of the Faculty of Economics and Administrative Sciences

Y. 2018, Volume 8, Issue 2, pp. 331-354

\title{
Makroekonomik Değişkenler ve Hisse Senedi Piyasası İlişkisi: KASE Örneği
}

\section{Aziza SYZDYKOVA \\ Ahmet Yesevi Üniversitesi, Ekonomi ve Finans Bölümü \\ azizayesevi@gmail.com}

Öz

Hisse senetleri yatırımcılar açısından en önemli yatırım araçları içerisinde yer almaktadır. Bu nedenle hisse senetleri fiyat hareketlerinin tahmini hem yatırımcıları hem de finans alanında çalışma yapan araştırmacıları yakından ilgilendirmektedir. Bugüne kadar literatürde hisse senedini etkileyen faktörleri ülke ve ülke grupları için araştıran ampirik çalışmalar çok sayıda yapılmıştır. Fakat Kazakistan hisse senedi piyasasını konu alan çalışmalar çok az sayıdadır. Bunun sebebi Kazakistan borsasının (KASE) yeni bir borsa olması ve diğer yandan daha yeni gelişmekte olan küçük borsa olmasıdır.

$\mathrm{Bu}$ çalışmada beş adet makro ekonomik değişken ile KASE borsa endeksi arasındaki ilişki açıklanmaya çalışılmıştır. Değişkenlerin istatistiksel açıdan anlamlılığını tespit etmek için EKK yöntemi, değişkenler arasındaki uzun dönemli ilişkinin varlığını araştırmak için Johansen eşbütünleşme testi, değişkenler arasındaki nedenselliğin açıklanması için hata düzeltme modeli ve Granger nedensellik analizi kullanılmıştır.

Anahtar kelimeler: Kazakistan, KASE, makroekonomik değişkenler, EKK, Eşbütünleşme, Granger Nedensellik

JEL kodları: G11, G15, G32, E44

Macroeconomic Variables and Equity Market Relation: KASE Example ${ }^{*}$

\begin{abstract}
Equity securities are among the most important investment instruments in terms of investors. For this reason, estimates of stock price movements concern closely both investors and researchers working in the field of finance. Until now, many empirical studies have been conducted on the factors affecting stocks in the literature for country and country groups but there are very few studies about Kazakhstan equity market. The reason is that Kazakhstan stock exchange (KASE) is a new stock exchange and on the other hand it is a newly emerging small stock exchange.

In this study, the relationship between the five macroeconomic variables and the KASE index was tried to be explained. The OLS in order to determine the statistical significance of the variables, Johansen cointegration test to investigate the existence of a long-run relationship between variables, error correction model for explaining the causality between variables and Granger causality analysis was used.
\end{abstract}

Keywords: Kazakhstan, KASE, macroeconomic variables, OLS, Cointegration, Granger Causality

JEL Codes: G11, G15, G32, E44

\footnotetext{
${ }^{*}$ Extended abstract is presented at the end of the article.
}

\section{Atıfta bulunmak için/Cite this paper:}

Syzdykova, A. (2018). Makroekonomik değişkenler ve hisse senedi piyasası ilişkisi: KASE örneği. Çankırı Karatekin Üniversitesi İ̈BF Dergisi. 8 (2), 331-354. 


\section{Giriş}

Hisse senetleri yatırımcılar açısından en önemli yatırım araçlarından biri olup, hisse senedinin fiyatlarını etkileyen çok sayıda faktör bulunmaktadır. Hisse senetleri fiyat hareketlerini önceden tahmin edip yüksek getiri sağlamak isteyen yatırımcılar, hisse senedi fiyatlarına etki eden faktörleri yakından takip ederek bu faktörlerde meydana gelebilecek değişimlere karşı yatırım stratejileri oluşturmaktadır. Aynı zamanda araştırmacılar hisse senedi fiyatlarına etki eden değişik türdeki faktörleri inceleyerek bu faktörlerin hisse senetleri fiyatlarına nasıl etki ettiklerini çeşitli modeller yardımıyla açıklamaya çalışmaktadır.

Hisse senedi fiyatları ile makroekonomik değişkenler arasındaki ilişki üzerine yapılan ampirik çalışmalarda farklı değişkenler kullanılmıştır: $\mathrm{Bu}$ konu üzerine odaklanan çalışmalar bu ilişkiyi; para piyasasını temsil eden (para arzı, faiz oranı), mal piyasasını temsil eden (sanayi üretimi, gayri safi yurtiçi hasıla, işsizlik oranı, enflasyon oranı, TÜFE, dış ticaret dengesi, ihracat-ithalat, tüketim hacmi), küresel değişkenler (döviz kuru, petrol fiyatı, MSCI Dünya endeksi, S\&P 500 endeksi) ve diğer değişkenler (bütçe açığı, doğrudan yabancı yatırımlar, portföy yatırımları) açısından modellemişlerdir (Özer vd., 2011; Albayrak vd.,2012). Yapılan çalışmalarda araştırma yapılan ülkelerin makroekonomik koşullarına göre hisse senedini etkileyen makroekonomik göstergelerin farklılık gösterdiği görülmüştür.

Literatürde yer alan ampirik çalışmaların sonucunda hisse senedi fiyatlarını etkileyen faktörlerin birçoğu bilinmektedir, fakat bu faktörlerin hisse senedi fiyatlarını ne şekilde ve ne zaman etkileyebileceğini belirlemek oldukça zordur. Diğer yandan ekonomik ve piyasadan kaynaklanan faktörler hisse senedi fiyatlarındaki değişimleri açıklamakta her zaman yeterli olmamaktadır. Çünkü hisse senedi fiyatlarındaki değişimler yatırımcıların psikolojik davranışlarından da kaynaklanabilmektedir. Piyasa koşullarında hiçbir değişikliğin olmadığı halde hisse senedi fiyatlarındaki dalgalanmalar yatırımcıların psikolojik davranışları ile açıklanabilmektedir (Özer vd.,2011).

Literatürde hisse senedi getirileri ile makroekonomik değişkenler arasındaki ilişki üzerine yapılan ampirik çalışmaların çoğunluğu [Fama (1981), Geske ve Roll (1983), Chen vd., (1986), Pearce ve Roley (1988), Asprem (1989), Abdullah ve Hayworth (1993), Thornton (1993), Barrows ve Naka (1994), Mukherjee ve Naka (1995), Nasseh ve Strauss (2000), Ratanapakorn ve Sharma (2007), Humpe ve Macmillan (2009), Lee ve Brahmasrene (2018)] özellikle ABD piyasası olmak üzere gelişmiş piyasalar için gerçekleştirilmiştir.

Hisse senedi getirileri ile makroekonomik değişkenler arasındaki ilişkiyi gelişen piyasalar için araştıran çalışmalara; [Singapur için Mookerjee ve Yu (1997), Maysami ve Koh (2000), Güney Kore için Kwon vd.(1997), Kwon ve Shin (1999), Gong ve Mariano (1997), Malezya için Ibrahim (1999), Mısır için Omran 
ve Pointon (2001), Ibrahim ve Aziz (2003), Brezilya için Adrangi vd.(2002), Yunanistan için Diacogniannis vd.(2001), Hindistan için Agrawalla ve Tuteja (2008), Das (2017), Türkiye için Kandir (2008), Büyüksalvarci ve Abdioglu (2010), BRIC ülkeleri için Gay (2016), Güney Afrika için Ndlovu vd., (2018)] çalışmaları örnek verilebilmektedir.

$\mathrm{Bu}$ konuda Kazakistan borsası için yapılmış çalışmalar yok denecek kadar azdır. Dolayısıyla bu çalışmanın literatüre katkı sağlaması düşünülmektedir. Çalışma 6 bölümden oluşmakta olup, takip eden bölümde Kazakistan ekonomisi ve borsası hakkında genel bilgiler verilmiştir. 3.bölümde Kazakistan borsası, benzer gelişmekte olan ülke borsaları ile karşılaştırılmıştır. Daha sonra konu ile ilgili geniş bir literatür yapılmıştır. 5. ve 6.bölümde araştırmanın veri seti, model ve yöntem açıklandıktan sonra bulgulara yer verilmiştir. Çalışma sonuç kısmıyla son bulmuştur.

\section{Kazakistan Ekonomisi ve Menkul Kıymetler Borsası}

Kazakistan Cumhuriyeti 1991 yılında Sovyetler Birliğinin dağılmasıyla birlikte bağımsızlığını kazandıktan sonra 1998 yılına kadar piyasa ekonomisi koşullarına geçişin zorluklarını yaşamıştır. 2000'li yıllarda petrol fiyatlarındaki yükselmeyle birlikte, ülkedeki reel GSYH önemli ölçüde artarken; diğer yandan üretim, istihdam ve dış ticaret açısından petrol sektörüne bağımlı bir yapı ortaya çıkmıştır (Togay, 2009).

Aşağıdaki Tablo 1'de Kazakistan'ın 2010-2016 yılındaki ekonomik durumunu gösteren veriler yer almaktadır.

Tablo 1: Kazakistan'ın Temel Makroekonomik Göstergeleri (2000-2016)

\begin{tabular}{|l|r|r|r|r|r|r|r|}
\hline & 2010 & 2011 & 2012 & 2013 & 2014 & 2015 & 2016 \\
Nüfus (milyon kişi) & 16,3 & 16,5 & 16,8 & 17,1 & 17,3 & 17,5 & 17,8 \\
GSYH (milyar ABD doları) & 148,1 & 192,6 & 207,9 & 236,6 & 221,4 & 184,4 & 137,3 \\
GSYİH büyümesi (yıllı\%) & 7,30 & 7,40 & 4,80 & 6,00 & 4,20 & 1,20 & 1,10 \\
Kişi başına düşen GSYİH (ABD doları) & 9070 & 11634 & 12387 & 13890 & 12806 & 10509 & 7714 \\
Dış borç stoku (milyar ABD doları) & 119,1 & 124,3 & 135,5 & 149,7 & 157,7 & 153,4 & 163,7 \\
Dış borç/GSYİH (\%) & 92,5 & 75,3 & 75,3 & 70,7 & 79,3 & 88,6 & 135,1 \\
İşsizlik oranı (\%) & 5,8 & 5,4 & 5,3 & 5,2 & 5,1 & 4,9 & 5,0 \\
Enflasyon (\%) & 7,12 & 8,35 & 5,11 & 5,84 & 6,72 & 6,65 &, \\
İhracat (milyar ABD doları) & 65,5 & 89,5 & 91,7 & 90,9 & 86,9 & 52,9 & 43,6 \\
İthalat (milyar ABD doları) & 44,2 & 51,3 & 61,6 & 63,4 & 56,7 & 45,2 & 38,9 \\
Cari işlemler dengesi/GSYİH (\%) & 0,94 & 5,29 & 0,51 & 0,54 & 2,77 & $-2,78$ & $-6,5$ \\
Rezervler (altın dahil, milyar ABD doları) & 28,3 & 29,2 & 28,3 & 24,7 & 29,3 & 27,8 & 29,4 \\
Rezervler/Toplam diş borç (\%) & 23,72 & 23,5 & 20,88 & 16,49 & 18,55 & 18,16 & 18,08 \\
DYY (milyar ABD doları) & 7,5 & 13,8 & 13,6 & 10,1 & 7,2 & 6,2 & 16,9 \\
\hline
\end{tabular}

Kaynak: Dünya Bankası, 2018 (Dünya Gelişim Göstergeleri) 
Tablo 1 incelendiğinde, Kazakistan'ın toplam nüfusu her geçen yıl bir önceki yıla göre artmaktadır. 2010 yılında 16,3 milyon kişi olan Kazakistan nüfusu 2016 y1lı sonu itibariyle 17,8 milyon kişiye ulaşmıştır. $\mathrm{Bu} 6$ yıl içerisinde Kazakistan nüfusu \%9,2 oranında arttığı anlamına gelmektedir. Kazakistan'ın GSYİH'si 2010-2013 yıllarında istikrarlı bir şekilde artış gösterirken, 2014 yılından sonra önemli derecede ekonomide küçülme yaşanmıştır. Bunun sebebi ise dünya petrol fiyatlarındaki yaşanan düşüşten kaynaklanmaktadır. 2013 yılında petrol fiyatları yıllık ortalama 108,56 dolar/varil iken, 2014 y1lının Eylül ayından itibaren düşüşler yaşanmış ve Kasım 2014'te petrolün varil fiyatı 79 dolar, Aralık 2014'te ise 62 dolara kadar gerilemiştir. Ocak 2016 tarihinde petrolün varil fiyatı 30,6 dolar seviyesini görmüştür ${ }^{\dagger}$. Petrol fiyatlarındaki bu düşüşler petrol ihracatçı konumunda olan Kazakistan ekonomisini derinden etkilemiştir. Nitekim 2013 yılında Kazakistan'ın GSYIH's'si 236,6 milyar dolar iken, 2016 yılında ise 137,3 milyar dolara kadar gerilemiştir. GSYİH rakamlarındaki düşüş ve nüfus oranındaki artışa bağlı olarak kişi başına düşen milli gelirin de yıllar itibariyle azaldığı görülmektedir. Ayrıca 2014 yılına kadar cari fazla vermekte iken 20152016 yılında cari açık vermiştir. Bu senaryodan bile Kazakistan ekonomisinin petrol fiyatlarına ne kadar duyarlı olduğunu görmek mümkündür.

Kazakistan'ın dış borç stoku yılar itibariyle arttığı görülmektedir, 2016 yılında dış borç stoku toplam 163,7 milyar doları oluşturmaktadır. Diş borç stokunun yapısı incelendiğinde; dış borç stoku içinde kamu kesiminin payı \%8,4 ve özel sektörün payı ise \%91,6'dır. Ayrıca Kazakistan'ın toplam dış borcunun \%95,8'i uzun vadeli borçlardan oluşmaktadır. Uzun vadeli borçlar içinde yabancı ülkelerin yaptıkları doğrudan yabancı yatırımdan kaynaklanan şirketler arası borçların payı çok yükssektir. Ayrıca Kazakistan'ın yaklaşık 120 ülkeye borcu bulunurken, diş borçlarının \%85'lik kısmı sadece 11 ülkeye aittir. Bu ülkeler sırasıyla; Hollanda, ABD, Fransa, Japonya, Bermuda Adaları, İngiltere, Rusya, Virjin Adaları, Güney Kore, Çin, Hong Kong ve İsviçre'dir (Kazakistan Ulusal Bankası, 2018).

Kazakistan Menkul Kiymetler Borsas1 (KASE) 17 Kasım 1993 tarihinde kurulmuştur. Borsanın Kurucuları ise Kazakistan Cumhuriyeti Ulusal Bankası ${ }^{\star}$ nın liderliğindeki önde gelen 23 Kazak bankasıdır. Kazakistan'ın ulusal para biriminin (tenge) tedavüle çıkarılması ile birlikte borsanın başlıca görevi ulusal para piyasasının organizasyonu ve geliştirilmesi olarak belirlenmiştir. Kazakistan Ulusal Bankası, KASE'in en büyük hissedarı olup, mevcut hisselerin \% 50,1'ine sahiptir.

\footnotetext{
Petrol fiyatları ile ilgili veriler Amerikan Enerji Ajansından elde edilmiştir (https://www.eia.gov/dnav/pet/hist/LeafHandler.ashx?n=PET\&s=RBRTE\&f=A) Erişim: 25.05 .2018

* Kazakistan Ulusal Bankası, 13 Nisan 1993 tarihinde kurulmuş olan Kazakistan’ın Merkez Bankasıdır. (www.nationalbank.kz)
} 


\section{Kazakistan Borsasının Gelişmekte Olan Ülke Borsaları İle Karşılaştırması}

Gelişmekte olan ülkelerdeki hisse senedi piyasaları hızla büyümekte olan piyasalar olup, risk ve getiri açısından gelişmiş ülke piyasalarından farklı özelliklere sahiptirler. Gelişmekte olan hisse senedi piyasaları, gelişmiş piyasalara nazaran daha yüksek ortalama getiri sağlar ve daha yüksek oynaklık gösterebilmektedir. Diğer yandan gelişmiş piyasa getirileri ile düşük korelasyona sahiptirler (Bekaert ve Harvey, 1997: 30).

Aşağıdaki Tablo 2 ve Şekil 1'de Kazakistan borsası ile kıyaslanabilir olduğu düşünülen, gelişmekte olan benzer ülkelerin sermaye piyasaları dikkate alınarak bazı karşılaştırmalar yapılmıştır. Kazakistan borsasına 85 şirket kayıtlı olup, piyasa kapitalizasyon değeri 40,1 milyar doları oluşturmaktadır.

Tablo 2: Gelişmekte Olan Ülke Borsalarının Karşılaştırması

\begin{tabular}{|c|c|c|c|c|}
\hline & $\begin{array}{l}\text { Piyasa } \\
\text { Kapitalizasyonu/GSYİH }\end{array}$ & $\begin{array}{l}\text { Piyasa } \\
\text { Kapitalizasyonu } \\
\text { (milyar ABD doları) }\end{array}$ & Şirket Sayısı & $\begin{array}{l}\text { İşlem Hacmi } \\
\text { (milyar } \\
\text { ABD doları) }\end{array}$ \\
\hline Arjantin & 11,7 & 63,6 & 93 & 4,4 \\
\hline BAE & 61,1 & 213,2 & 125 & 49,4 \\
\hline Bahreyn & 60,3 & 19,4 & 43 & 0,332 \\
\hline Belarus & - & - & 55 & - \\
\hline Fas & 55,6 & 57,5 & 74 & 3,2 \\
\hline Kazakistan & 29,3 & 40,1 & 85 & 0,741 \\
\hline Kibris & 12,5 & 2,5 & 81 & 0,074 \\
\hline Kolombiya & 36,8 & 103,8 & 68 & 14,1 \\
\hline Macaristan & 17,9 & 22,5 & 43 & 7,8 \\
\hline Mauritius & 62,2 & 7,5 & 75 & 319,5 \\
\hline Meksika & 33,5 & 350,8 & 137 & 111,9 \\
\hline Romanya & - & - & 84 & - \\
\hline Rusya & 48,5 & 622,0 & 242 & 139,5 \\
\hline Slovenya & 11,8 & 5,2 & 38 & 305,7 \\
\hline Suudi Arabistan & 69,4 & 448,8 & 176 & 306,3 \\
\hline Tunus & 20,1 & 8,4 & 79 & - \\
\hline Türkiye & 19,9 & 171,7 & 380 & 281,8 \\
\hline Ukrayna & - & - & 121 & - \\
\hline Umman & 35,1 & 23,2 & 113 & 2,4 \\
\hline
\end{tabular}

Not: - : veri yoktur.

Kaynak: WFE, 2017

2016 yılında, KASE de dahil olmak üzere gelişmekte olan ülkelerin borsa endeksleri iyi bir performans göstermişlerdir. 2016 yılındaki ABD doları cinsinden en yüksek getirileri sağlayan borsaların ilk beşi sırasıyla; Brezilya, Rusya, Macaristan, Fas ve Kazakistan borsalarıdır (Şekil 1). Fakat 2015 yılında Macaristan ve Rusya borsası hariç diğer üç borsa negatif getiri sağlayan borsalard1. Brezilya borsas 2015 y1lında \%44, Kazakistan borsas1 \%47, Fas borsası ise \%13 kaybettirmişti (WFE, 2017). Şekil incelendiğinde Nijerya borsasının yüksek negatif getirisi dikkat çekmektedir. 2016 yılındaki bu düşüşün 
sebebi petrol fiyatlarındaki düşüşler ve ekonomideki döviz kuruyla ilgili bazı belirsizliklerden kaynaklanmıştı. Görüldüğü gibi gelişmekte olan ülke borsaları yüksek getiri oranları ile dikkat çekmektedir. Söz konusu borsalar dünya borsası ile düşük korelasyona sahip olup, derinliği fazla olmasa da yatırımcılara portföy risklerini elimine etme imkanı sunabilmektedir.

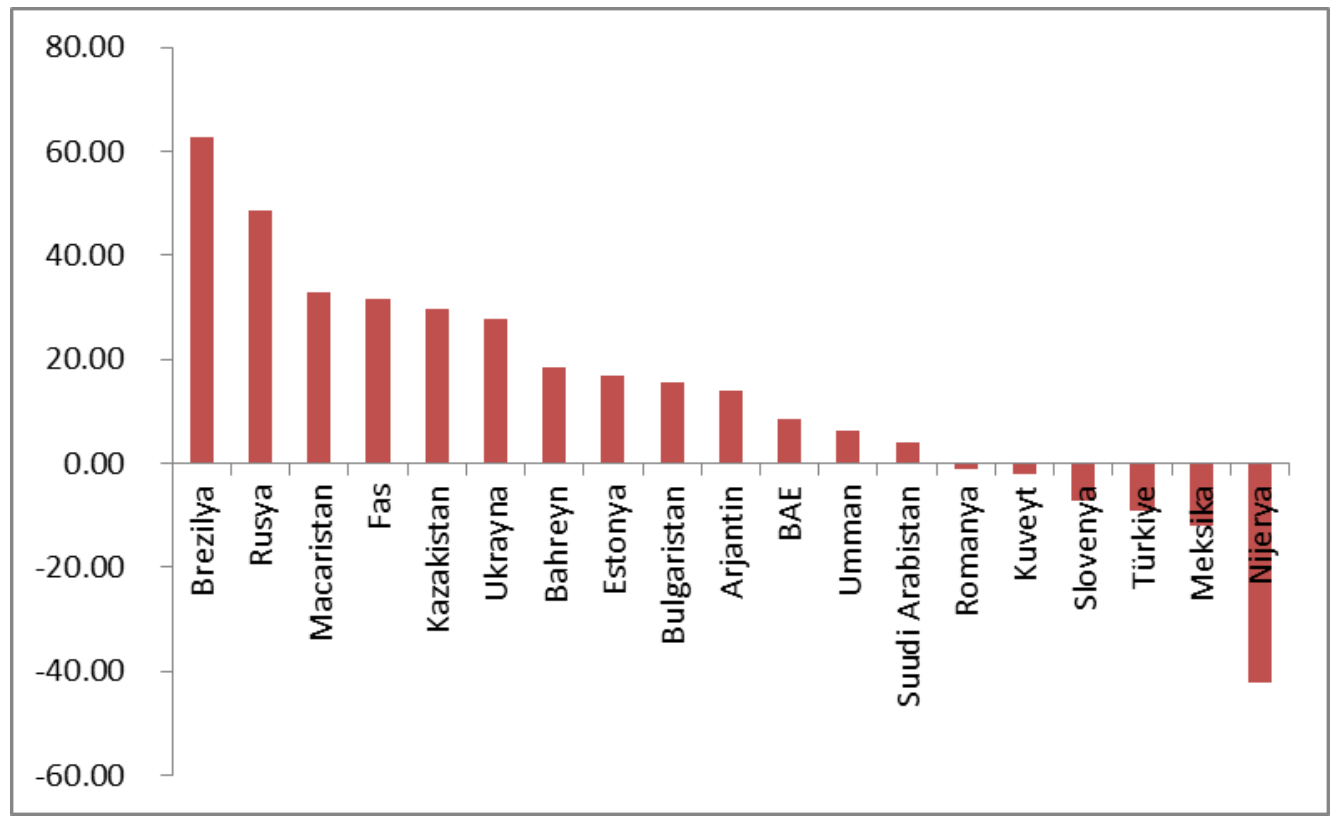

Şekil 1: ABD doları bazında KASE ve Gelişmekte Olan Endeks Getirileri (2016)

Kaynak: WFE, 2017

\section{Literatür Taraması}

Literatür incelendiğinde hisse senedi fiyatlarını etkileyen faktörleri genel olarak işletme düzeyindeki faktörler ve makro ekonomik faktörler olmak üzere iki başlık altında incelemek mümkündür. Hisse senedini etkileyen işletme düzeyinde faktörler firmaların kendi bünyesinde meydana gelen değişimlerden kaynaklanır. Hisse senedini halka arz eden firmanın karlılık durumu, finansal yapısı, sermaye artırımı, temettü politikası, finansal tablolardaki değerler gibi faktörler hisse senedi fiyatlarına etki etmektedir (Bakkal vd.,2012: 103). Hisse senedi fiyatlarını etkileyen makroekonomik değişkenler ise en genel tanımıyla ülkenin ekonomik performansını gösteren değişkenlerdir. Bu grupta döviz kuru, para arzı, faiz oranları, gayri safi milli hasıla (GSMH), cari işlemler dengesi gibi faktörler yer almaktadır (Aktaş ve Akdağ, 2013).

$\mathrm{Bu}$ iki grup faktörün dışında hisse senedi fiyatlarını etkileyen uluslararası faktörler (petrol fiyatları, altın fiyatları, S\&P endeksi gibi), siyasi faktörler ve yatırımcıların psikolojileri ile ilgili birçok faktör bulunmaktadır. Bugüne kadar hisse senedi 
fiyatlarını etkileyen faktörleri araştıran ampirik çalışmalarda söz konusu faktörlerin sayısal olarak ölçülebilenleri ile siyasi veya psikolojik faktörlerin bazıları modele kukla değişken şeklinde dahil edilmiştir. Aşağıda bu konuda yapılmış ampirik çalışmalar tarihine göre sıralı bir şekilde açıklanmaktadır.

Muradoğlu vd.,(2000) çalışmalarında 19 gelişen piyasada hisse senedi fiyatları ile makroekonomik değişkenler arasındaki nedensellik ilişkisini incelemişlerdir. Çalışmada yerel değişkenler olarak; yerel piyasa hisse senedi getirisi, enflasyon, sanayi üretim endeksi, döviz kuru ve faiz oranı, küresel değişken olarak ise dünya piyasa portföyünü ve piyasa liberalizasyon derecesini kontrol eden S\&P 500 endeksi getirisini kullanılmışlardır. Çalışma sonucunda 1976-1997 döneminde Çin, Arjantin ve Brezilya'da enflasyon ve faiz oranının, Pakistan ve Zimbabwe'de sadece faiz oranının hisse senedi getirisinin nedeni olduğunu ortaya çıkarmışlardır. Brezilya, Kolombiya, Yunanistan, Güney Kore, Meksika ve Nijerya gibi ülkelerde döviz kurunun hisse senedi getirisini etkilediğini sadece Kolombiya, Meksika ve Portekiz'de yerel hisse senedi getirilerinin S\&P 500 endeksiyle ilişkili olduğunu bulmuşlardır.

Bhattacharya ve Mukherjee (2002) çalışmalarında Hindistan hisse senedi piyasasıyla seçilen 5 makroekonomik değişken (para arzı, sanayi üretim endeksi, faiz oranı, mili gelir ve enflasyon oranı) arasındaki ilişki 1992-2001 yılları arasında araştırılmıştır. Hindistan'da borsanın ekonominin barometresi olup olmadığı araştırılmıştır. Bu araştırma yapılırken birim kök testi, eşbütünleşme analiz ve Toda-Yamamoto nedensellik analizinden faydalanmıştır. Bulgulara göre hisse senedi fiyatları ile para arz1, milli gelir ve faiz oranı arasında herhangi bir ilişki bulunamamıştır. Sanayi üretim endeksinden hisse senedi fiyatlarına doğru tek yönlü ve enflasyon değişkeni ile hisse senetleri arasında çift yönlü nedensellik ilişkisi mevcuttur. Bununla birlikte hisse senedi piyasasının sanayi üretim endeksi ve enflasyon oranı dikkate alındığında bilgi anlamında etkisiz olduğu belirtilmiş ve bu iki değişkendeki değişiklikler hakkındaki bilgi sayesinde anormal karlar elde edile bileceği belirtilmiştir.

Patra ve Poshakwale (2006) çalışmalarında Yunanistan borsası için 1990-1999 dönemine ait aylık verileri kullanarak hisse senedi fiyatları ve makroekonomik değişkenler arasındaki kısa ve uzun dönem denge ilişkisini araştırmışlardır. Ampirik sonuçlar, Atina borsasında enflasyon, para arzı ve işlem hacmi ile hisse senedi fiyatları arasında kısa ve uzun dönemli denge ilişkisinin varlığını göstermiştir. Döviz kurları ile hisse senedi fiyatları arasında hem kısa hem de uzun dönemde denge ilişskisi bulunamamıştır. Döviz kuru ile hisse senedi fiyatları arasındaki ilişkinin olmayışını Yunanistan hükümetinin Avrupa Para Birliği'ne girmek için uygulanan politikalardan kaynaklandığını ifade etmişlerdir. Diğer bir bulguya göre yazarlar; örnek dönem boyunca makroekonomik değișkenler ve işlem hacimleri hakkındaki kamuya açık bilgilerin Yunan borsasında hisse senedi fiyatlarının tahmininde kullanılabileceğini savunmuştur. 
Singh (2010) çalışmasında Hindistan borsası kapanış fiyatları ile üç temel makro ekonomik değişken (toptan eşya fiyat endeksi, sanayi üretim endeksi ve döviz kuru) arasındaki nedensellik ilişkisini Nisan 1995-Mart 2009 dönemine ait verileri kullanarak araştırmıştır. Bulgulara göre; Hindistan borsası ile sanayi üretim endeksi değişkenleri arasında çift yönlü nedensellik ilişkisi mevcuttur. Diğer yandan borsa kapanış fiyatları ile döviz kuru ve toptan eşya fiyat endeksi arasındaki güçlü korelasyon ilişkisine rağmen nedensellik ilişkisi bulunamamıştır.

Al-Jafari vd. (2011) çalışmasında Ocak 2002-Aralık 2008 dönemine ait verileri kullanarak gelişmiş ve gelişmekte olan piyasalarda hisse senedi fiyatları ve makroekonomik değişkenler arasındaki ilişkiyi incelemişlerdir. Kullanılan makro ekonomik değişkenler; tüketici fiyat endeksi, sanayi üretim endeksi, para arzı, döviz kuru ve faiz oranlarıdır. Çalışmada Pedroni panel eşbütünleşme ve Granger nedensellik testi kullanılmıştır. Ampirik sonuçlar gelişmiş ve gelişmekte olan piyasalarda hisse senedi fiyatları ile faiz oranı ve para arzı hariç diğer makroekonomik değişkenler arasında önemli bir nedensel ilişki göstermiştir. Bir diğer bulgu ise reel ekonomik aktivite düzeyi ve gelişmiş piyasalardaki hisse senedi fiyatları arasında uzun vadede olumlu bir ilişki olduğu bulunmuştur.

Issahaku vd.,(2013) çalışmalarında Gana'daki makroekonomik değişkenler ile hisse senedi getirileri arasındaki nedensellik ilişkisini Ocak 1995 ile Aralık 2010 dönemine ait aylık zaman serisi verilerini kullanarak incelemişlerdir. Çalışmanın bulguları hisse senedi getirileri ile enflasyon, para arzı ve doğrudan yabancı yatırım arasında önemli bir uzun dönemli ilişki bulunduğunu ortaya koymuştur. Kısa dönemde, hisse senedi getirileri ile faiz oranı, enflasyon ve para arzı gibi makroekonomik değişkenler arasında anlamlı bir ilişki bulunmuştur. Nedensellik analizi bulgularına göre; enflasyon ve döviz kurundan hisse senedi getirilerine doğu tek taraflı bir nedensellik ilişkisi mevcuttur. Diğer yandan hisse senedi getirisinden para arzına, faiz oranına ve doğrudan yabancı yatırımlara doğru nedensellik ilişkisi bulunmuştur.

Güngör ve Kaygın (2015) çalışmasında Türkiye borsası için yaptığı çalışmasında Dinamik Panel Veri Analizi kullanarak hisse senedi fiyat hareketlerini belirleyen değişkenleri makroekonomik ve mikro ekonomik olarak incelemiştir. Yapılan analizler sonucunda mikro ekonomik faktörler hisse senedi fiyat değişimlerinin tahmin edilebileceği kanısına varılmış, ayrıca mikro ekonomik değişkenler ile hisse senedi oynaklıkları arasında anlamlı bir ilişki olduğu sonucuna ulaşmıştır. Çalışmada ele alınan makroekonomik değişkenlerden döviz kuru, para arzı, petrol fiyatları ve sanayi üretim endeksi ile hisse senedi fiyat değişimleri arasında pozitif yönlü ilişki, enflasyon oranı, faiz oranı, GSYİH, altın fiyatları ve dış ticaret dengesi arasında negatif yönlü iliş̧i olduğu sonucuna varılmıştır.

Lee ve Brahmasrene (2018) çalışmasında Kore Borsasında seçilen makroekonomik değişkenler ile hisse senedi fiyatları arasındaki kısa ve uzun vadeli dinamik ilişkiler incelenmiştir. Ocak 1986- Ekim 2016 dönemine ait 
verilerin kullanıldığ 1 çalışmada uzun dönem ilişkinin incelenmesi için Johansen eşbütünleşme testi ve kısa dönem ilişkisinin tahmini için hata düzeltme modeli kullanılmıştır. Sonuçlara göre Kore'de hisse senedi fiyatları ile makroekonomik değişkenler arasında uzun dönemli bir denge ilişkisi mevcuttur. Hata düzeltme modeli tahminlerinin sonuçları, para arzı ve kısa vadeli faiz oranının kısa vadede hisse senedi fiyatları ile ilgili olmadı̆̆ını göstermiştir. Bununla birlikte, döviz kurunun hisse senedi fiyatları ile pozitif ilişkili olduğu, sanayi üretim endeksi ve enflasyonun ise kısa vadede hisse senedi fiyatları ile negatif ilişkili olduğu görülmüştür. Ayrıca, VECM tahminleri, bölgesel ve küresel finansal kriz şokları gibi dışsal şokların endojen değişkenlerdeki değişimleri etkilemediğini ve eşbütünleşme vektöründe kararsızlığa neden olmadığını göstermiştir.

Ndlovu vd., (2018) çalışmasında Johannesburg borsası için 1981- 2016 dönemine ait çeyreklik verilerle makroekonomik değişkenler (enflasyon, para arzı, faiz oranı ve döviz kuru) ile hisse senedi fiyatları arasındaki ilişkiyi eşbütünleşme testi ve vektör hata düzeltme modeline dayalı nedensellik testini kullanarak araştırılmışlardır. Sonuçlara göre; uzun vadede faiz oranları, para arzı ve enflasyonun hisse senedi fiyatı ile pozitif ilişkisi vardır. Döviz kuru ile hisse senedi fiyatı arasında negatif ilişki bulunmuştur. Bununla birlikte döviz kurundan ve faiz oranlarından hisse fiyatına doğru tek yönlü nedensellik tespit edilmiştir.

Kazakistan borsasını konu alan çalışmalar ise Yalçın (2015) ve Syzdykova (2017) çalışmalarıdır. Yalçın (2015) çalışmasında Ocak 2000-Temmuz 2013 dönemine ait verilerle petrol fiyatlarında arz veya talep şoklarından dolayı gerçekleşen artışların Rusya, Kazakistan ve Ukrayna borsalarını olan etkilerini SVAR modeli ile incelenmiştir. Çalışmada ele alınan dönem 2008 krizini içerdiği için önce tüm dönem ve sonrasında kriz öncesi ve kriz sonrası olacak şekilde 2 alt döneme ayırarak analiz yapılmıştır. Çalışmanın bulgularına göre petrol arzından kaynaklanan şokların tüm ve alt dönemlerde KASE endeks getirisi üzerinde etkili olmadığı bulunmuştur. Petrole özgü talep şoku ise 2008 krizi sonrası dönemde KASE borsasını ilk ay istatistiksel olarak anlamlı olacak şekilde artırmaktadır. Diğer tüm dönemlerde etkinin anlamsız olduğu sonucuna ulaşılmıştır. Genel olarak petrol fiyatlarını Kazakistan'daki tüketim belirlemediği sürece petrol fiyatlarının Kazakistan borsasını etkilemediğini savunmaktadır.

Syzdykova (2017) çalışmasında Ocak 2000-Mart 2017 dönemine ait verilerle petrol fiyat değişimleri ile KASE borsası arasındaki ilişki incelenmiştir. Johansen eşbütünleşme testi sonuçlarına göre değişkenler arasında uzun dönemli bir ilişki tespit edilmiştir. Hata düzeltme modeline dayalı Granger nedensellik testi sonuçlarına göre petrol fiyatlarından hisse senedi getirilerine doğru tek yönlü ilişki bulunmuştur. 
Literatürde hisse senedi fiyatlarını etkileyen faktörleri araştıran çalışmalar çokça vardır ve sonuçları bakımından bir birinden farklılık göstermektedir. Bunun nedeni aslında analize dahil edilen ülke veya ülke gruplarının, uygulanan yöntemin ve çalışmaların kapsadığı veri seti ve dönemin farklı olmasından kaynaklanabilmektedir. Diğer yandan çalışmalarda modele dahil edilen değişkenler de farklı olabilmektedir.

\section{Veri Seti ve Yöntem}

\subsection{Kullanılan Veri Seti ve Model}

$\mathrm{Bu}$ araştırmada, bağımlı değişken olarak KASE kapanış fiyatları kullanılacaktır. Bağımsız değişkenler; ülkedeki temel makroekonomik değişkenler olan enflasyon oran1, faiz oran1, döviz kuru, sanayi üretim endeksidir. Bununla birlikte Kazakistan önemli petrol üreticisi ve ihracatçısı ülke olduğu için petrol fiyatlarının da borsayı etkileyeceği düşünülerek, petrol fiyatları da modele dahil edilmiştir. Analizde Haziran 2000- Nisan 2017 dönemi içinde yer alan 17 yıllık süreye ait aylık zaman serisi verileri kullanılacaktır ${ }^{\S}$.

Tablo 3: Veri Seti ve Kaynakları

\begin{tabular}{|c|l|l|}
\hline $\begin{array}{c}\text { Değişkenler } \\
\text { kase }\end{array}$ & $\begin{array}{l}\text { Açıklama } \\
\text { Borsa Endeksinden Hesaplanmıştır } \\
\left(\frac{P_{2}-P_{1}}{P_{1}}\right)\end{array}$ & $\begin{array}{l}\text { Kaynakları } \\
\text { Bloomberg veri tabanı }\end{array}$ \\
cpi & Tüketici fiyat endeksi $(2010=100)$ & IMF, IFS \\
$e r$ & Dolar karşısındaki tengenin değeri & IMF, IFS \\
ir & 3 aylık mevduat faizi & Kazakistan Ulusal Bankası \\
$i p$ & Sanayi üretim endeksi $(2010=100)$ & IMF, IFS \\
oilp & Brent ham petrol fiyatları & Uluslararası Enerji Ajans1 \\
\hline
\end{tabular}

Uygulama bölümünde kullanılan model ve modeldeki değişkenler belirlenirken literatürden yararlanılmıştır. Araştırma modeli Tablo 4'te detayları verilen Sadorsky (1999), Park ve Ratti (2008), Filis (2010), Celov ve Grigaliuniene (2010), Le ve Chang (2011), Li ve Wen (2012) tarafından gerçekleştirilen çalışmalardan yararlanılarak oluşturulmuştur.

\footnotetext{
${ }^{\S}$ Bu zaman aralığının seçilmesinin sebebi, KASE kapanış fiyatlarına ait verilere Haziran 2000 tarihinden itibaren ulaşılabilmiştir. Endeks verileri Bloomberg veri tabanından elde edilmiştir.
} 


\section{Tablo 4: Ampirik Çalışma İçin Örnek Modeller}

\begin{tabular}{|c|c|c|}
\hline Çalışma & Yöntem & Model \\
\hline $\begin{array}{l}\text { Sadorsky } \\
(1999)\end{array}$ & $\begin{array}{l}\text { VAR ve Genelleştirilmiş } \\
\text { Otoregresif Koşullu } \\
\text { Değişen Varyans } \\
\text { (GARCH) modeli }\end{array}$ & $\begin{array}{l}\text { Getiri=f(sanayi üretim endeksi, faiz oranları, reel } \\
\text { petrol fiyatları, S\&P endeks getirisi, enflasyon) }\end{array}$ \\
\hline $\begin{array}{l}\text { Park ve Ratti } \\
(2008)\end{array}$ & $\begin{array}{l}\text { Çok değişskenli VAR } \\
\text { modeli }\end{array}$ & $\begin{array}{l}\text { Getiri }=\mathrm{f}(\mathrm{k} 1 \mathrm{sa} \text { vadeli faiz oranları, enflasyon, sanayi } \\
\text { üretimi, petrol fiyat şokları) }\end{array}$ \\
\hline Filis (2010) & $\begin{array}{l}\text { Eşbütünleşme testi, } \\
\text { Vektör hata düzeltme } \\
\text { modeli }\end{array}$ & $\begin{array}{l}\text { Getiri=f(tüketici fiyatları endeksi, sanayi üretimi, } \\
\text { petrol fiyatları) }\end{array}$ \\
\hline $\begin{array}{l}\text { Celov ve } \\
\text { Grigaliuniene } \\
(2013)\end{array}$ & $\begin{array}{l}\text { Sabit etkiler panel veri } \\
\text { modeli }\end{array}$ & $\begin{array}{l}\text { Getiri=f(TÜFE, endüstri güven } \\
\text { endeksi, ihracat ve ithalat, reel ve nominal döviz } \\
\text { kuru, enflasyon, M2 para arzı, işsizlik oranı, SÜE) }\end{array}$ \\
\hline $\begin{array}{l}\text { Le ve Chang } \\
(2011)\end{array}$ & VAR modeli & Getiri $=\mathrm{f}$ (petrol fiyatlar1, döviz, faiz oranı) \\
\hline $\begin{array}{l}\mathrm{Li} \text { ve } \\
(2012)\end{array}$ & $\begin{array}{l}\text { Doğrusal olmayan } \\
\text { regresyon analizi }\end{array}$ & $\begin{array}{l}\text { Getiri=f(tüketici ve üretici fiyat endeksi, faiz } \\
\text { oranları, sanayi üretimi büyüme oranı ve ham } \\
\text { petrol fiyatları }\end{array}$ \\
\hline
\end{tabular}

Kaynak: Syzdykova, A. (2018: 11).

Bu çalışmalar ışığında araştırmanın modeli aşağıda gösterilmiştir:

$$
\operatorname{lnkase}_{t}=\beta_{0}+\beta_{1} \operatorname{lnip}_{t}+\beta_{2} \text { ir }_{t}+\beta_{3} \operatorname{lner}_{t}+\beta_{4} \operatorname{lncpi}_{t}+\beta_{5} \operatorname{lnoilp}_{t}+u_{t}
$$

Modeldeki değişkenler sırasıyla; kase- bağımlı değişken, hisse senedi kapanış fiyatını, ip- sanayi üretim endeksini, ir- faiz oranını, er- döviz kurunu, infTÜFE'yi, oilp- petrol fiyatlarını ifade etmektedir. In ifadesi değişkenlerin doğal logaritmasin 1 belirtirken, $u_{t}$ ise stokastik hata terimidir.

Çalışmada zaman serisi analizi yapılmış ve Eviews 8 ekonometrik paket programı kullanılmıştır.

\subsection{Araştırmanın Yöntemi}

Çalışmada değişkenler arasındaki istatistiksel ilişkinin belirlenmesi için En Küçük Kareler (EKK) yöntemi, uzun dönemli ilişkinin belirlenmesi için Johansen eşbütünleşme testi, bu ilişkilerin yönünün belirlenmesi için hata düzeltme modeline dayalı Granger nedensellik analizi kullanılmıştır.

EKK yöntemi, ana kütle regresyon modelindeki bağımlı değişken ve bağımsız değişken arasında ilişki kuran parametrelerin tahmin edilmesinde en çok kullanılan yöntemlerden biridir. EKK yöntemi kolay uygulanabilir olduğundan 
dolayı ampirik çalışmalarda diğer ekonometrik yöntemlere göre daha çok tercih edilmektedir (Çil Yavuz, 2014: 115).

EKK yöntemi, artık kareleri toplamını en aza indirerek parametrelerin hesaplandığı bir yöntemdir. Örnek regresyon modeli aşağıdaki gibidir:

$$
Y_{t}=\beta_{0}+\beta_{1} X_{1 t}+\beta_{2} X_{2 t}+u_{t}
$$

Eşitlikte yer alan hata terimlerini ifade eden $u_{t}$ 'lerin kare toplamlarını en aza indirilmeye çalışılır.

EKK yöntemi serilerin durağan seviyelerini göz önünde bulundurarak geliştirilmiş bir yöntemdir. Dolayısıyla durağan olmayan seriler EKK yöntemi ile analiz edildiğinde herhangi bir şoktan sonra değişkenler araksanabilir. $\mathrm{Bu}$ sorunun çözümü için serilerin farkı alınarak seriler durağan duruma getirilir. Ancak serilerin farkı alınınca serilere ait bilgi kaybı söz konusu olabilir. Böyle bir süreçte değişkenlerin uzun dönem denge bilgileri kaybolmaktadır. Ekonomik teorilerde denge uzun dönem ilişkisine dayanmaktadır (Üçdoğruk, 1996: 107).

Uzun dönem ilişkisini gösteren parametrelerin tahmin edilmesinde eşbütünleşme analizi kullanılmaktadır. Eşbütünleşme analizi, ekonomik değişkenler arasındaki uzun dönemli ilişkinin istatistiksel açıdan incelenmesidir. Kısaca eşbütünleşme analizi, durağan olmayan zaman serileri arasındaki korelasyonu incelemek için geliştirilmiş matematiksel bir yöntemdir.

Eşbütünleşme konusunda zaman içinde yaşanan gelişmelerde, nedensellik araştırılırken serilerin durağan olmaması ve aralarında bütünleşik yap1 kanıtlanamaması durumunda kisitsı VAR modellerinin kullanılabilmesidir. Bununla birlikte birik kök içeren fakat eşbütünleşme ilişkisi olan değişkenler arasındaki nedensellik ilişkilerinin Vektör Hata Düzeltme Modeli (VECM) kullanılarak tespit edilebilmektedir. Buradaki farklılığın sebebi ise, VAR modelinde değişkenlerin birinci sıra farklarının kullanılması söylenebilir. Analize değişkenlerin birinci sıra farkları dahil edildiğinde, değişkenler arasındaki uzun dönemli ilişkiler kaybolabilmektedir (Çelik, 2011).

Eşbütünleşik seriler arasında Engle-Granger (1987)'e göre, en azından tek yönlü bir nedensellik ilişkinin olmasıdır. Ampirik analizlerde değişkenler arasında eşbütünleşme ilişkisinin varlığı tespit edildiğinde, bu değişkenler arasındaki kısa dönemli nedensellik ilişkilerin VECM ile analiz edilmesi gerekmektedir. Eşbütünleşme ilişkisinden türetilmiş VECM ile geliştirilmiş Granger Nedensellik modeli, aşağıdaki eşitliklerde ifade edildiği gibidir (Tarı, 2008): 


$$
\begin{aligned}
& \Delta X_{t}=\alpha_{1}+\sum_{i=1}^{m} \beta_{1 i} \Delta Y_{t-1}+\sum_{i=1}^{n} \gamma_{1 i} \Delta X_{t-i}+\sum_{1=1}^{r} \delta_{1 i} E C T_{r, t-1}+u_{t} \\
& \Delta Y_{t}=\alpha_{1}+\sum_{i=1}^{m} \beta_{1 i} \Delta X_{t-1}+\sum_{i=1}^{n} \gamma_{1 i} \Delta Y_{t-i}+\sum_{1=1}^{r} \delta_{1 i} E C T_{r, t-1}+u_{t}
\end{aligned}
$$

3. ve 4. eşitliklerdeki $\Delta$ simgesi fark operatörünü, $E C T_{t-1}$ ise hata düzeltme terimini göstermektedir. İki eşitlikten de görüldüğü gibi açıklamak istenilen bağımlı değişkendeki değişmeye hem $\mathrm{X}$ hem Y'nin gecikmeli değerleri eklenmektedir. Bununla birlikte önceki dönemlerde ortaya çıkan hataların da bağımlı değişkeni ne düzeyde etkilediği ortaya konulmaya çalışılmaktadır. Yukarıdaki iki eşitlik yardımıyla kurulan hata düzeltme modelinin sonuçları, değişkenler arasındaki hem kısa dönem hem de uzun dönem nedenselliği bütün ayrıntısıyla gösterecektir (Tarı, 2008).

\section{Analiz Bulguları}

\subsection{Birim Kök Testi Sonuçları}

Zaman serileri analizinde kullanılacak verilerin öncelikle durağan olması gerekmektedir. Zaman serilerinin ham verileri genelde durağan değildir ve durağan olmayan serilerin ekonometrik modellerde kullanılması bir takım sorunlara yol açmaktadır. Durağan olmayan zaman serilerinin kullanılması halinde EKK yönteminde katsayıları ve $t$ dağılımları normal dağılıma uymamaktadır. Ayrıca sahte regreyon sorununa neden olabilmektedir ve gerçekte değişkenler arasında olmayan ilişkiler ortaya çıkabilir veya ekonometrik modelin açıklayıcılık gücünü gösteren $\mathrm{R}^{2}$ olduğundan daha yüksek çıkabilmektedir (Kurt 2004: 40). Dolayısıyla analize başlamadan önce değişkenlerin durağan olup olmadıkları birim kök testi ile araştırılmıştır. Modele dahil edilen değişkenlere ait birim kök testi sonuçları Tablo 5 'te verilmiştir.

\section{Tablo 5: ADF Birim Kök Testi Sonuçları}

\begin{tabular}{|c|c|c|c|c|c|c|c|}
\hline & \multicolumn{3}{c|}{ Seviye } & \multicolumn{4}{c|}{ Birinci S1ra Farklar } \\
Değişkenler & Gecikme & t-istatistiği & p-değeri & Değişkenler & Gecikme & t-istatistiğ & p-değeri \\
lnkase & 3 & -1.550866 & 0.8086 & $\Delta$ lnkase & 0 & -9.353051 & 0.0000 \\
lnoill & 10 & -1.277393 & 0.8903 & $\Delta$ lnoill & 9 & -4.497083 & 0.0020 \\
lnip & 12 & -1.708815 & 0.7437 & $\Delta$ lnip & 12 & -4.296670 & 0.0040 \\
lncpi & 4 & -1.960009 & 0.6189 & $\Delta$ lncpi & 3 & -6.659047 & 0.0000 \\
lner & 1 & -1.134787 & 0.9196 & $\Delta$ lner & 0 & -8.551700 & 0.0000 \\
ir & 9 & -3.419277 & 0.03018 & - & - & - & -
\end{tabular}

ADF regresyon eşitliği deterministik bileşenlerden hem sabit terim hem de trend içermektedir. $\Delta$ : Birinci sıra fark işlemcisidir. 
ADF birim kök testi sonuçlarına göre modele dahil edilen değişkenlerden \%5 anlamlılık düzeyinde faiz oranı hariç bütün değişkenler seviyede birim kök içermekte iken birinci sıra farkları alındığında birim kök içermemektedir. Bu sonuçlar, faiz oranı hariç diğer değişkenlerin tamamı için bütünleşme sırasının 1 olduğunu göstermektedir.

\subsection{EKK Tahmin Sonuçları}

EKK yöntemi değişkenler arasındaki ilişkinin istatistiki olarak anlamlılığı ve bağımsız değişkenlerin bağımlı değişkeni nasıl etkilediği hakkında bilgi verir. Aşağıdaki Tablo 6'da EKK tahmin modeline ait istatistiksel testlerin sonuçları bulunmaktadır. Değişkenlerin aldığı değerler \%5 anlamlılık düzeyinde test edilmiştir.

Tablo 6: EKK Tahmin Sonuçları

\begin{tabular}{|c|c|c|c|c|}
\hline Değişken & Katsayı & Std. hata & t-istatistiği & p-değeri \\
\hline $\mathrm{c}$ & 12.96073 & 2.208481 & 5.86861 & 0.0000 \\
\hline$\Delta l c p i$ & -1.01918 & 0.65562 & 0.07135 & 0.5521 \\
\hline$\Delta l i p$ & 0.012951 & 0.07135 & 0.07567 & 0.8563 \\
\hline$\Delta$ ler & -1.724267 & 0.341660 & -5.04673 & 0.0000 \\
\hline$i r$ & -0.098582 & 0.045708 & 5.90874 & 0.4061 \\
\hline Aloil & -1.148980 & 0.285318 & -4.02701 & 0.0001 \\
\hline $\mathbf{R}^{2}$ & 0.628410 & & & \\
\hline Düzeltilmiş $\mathrm{R}^{2}$ & 0.623941 & & & \\
\hline F- istatistiği & 185.3892 & & & \\
\hline Olasılık değeri (F- istatistiği) & 0.000000 & & & \\
\hline Durbin-Watson stat & 1.974848 & & & \\
\hline
\end{tabular}

Analize genel olarak bakıldığında modelin anlamlılığını gösteren F-istatistiğine ait olasılık değerleri \%5'ten küçüktür ve modelin bütünü istatistiki olarak anlamlıdır. $\mathrm{R}^{2}$ değerinin \%62 olduğu görülmektedir. Bunun anlamı bağımsız değişkenlerde meydana gelen değişimler bağımlı değişkeni yaklaşık olarak \%62 oranında açıklamaktadır.

Tablo 6'dan görüldüğü gibi modele dahil edilen bağımsız değişkenlerden petrol fiyatı ve döviz kuru değişkenleri istatistiki olarak anlamlı olup, borsayı negatif etkilemektedir. Döviz kurunda meydana gelen \%1'lik artış borsayı \%1.72 oranında azaltırken, petrol fiyatlarındaki \%1'lik artış \%1.14 oranında düşürmektedir.

Diğer değişkenlerin olasılık değerlerine bakıldığında \%5'ten büyük olduğu için $\mathrm{H}_{0}$ reddedilemez, dolayısıyla söz konusu değişkenler borsayı açıklamakta istatistiki olarak anlamsızdır. 


\subsection{Eşbütünleşme Testi Sonuçları}

Eşbütünleşme analizi yapabilmek için değişkenlerin aynı seviyede durağan olmaları gerekir. Sabitli, trendli ve sabitli birim kök testi sonuçlarına göre faiz oranı hariç diğer değişkenlerin aynı seviyede durağan olduğu görülmüştür. $\mathrm{Bu}$ sonuçlar eşbütünleşme testinin faiz oranı dışındaki diğer tüm değişkenlere uygulanabileceğini göstermektedir.

Johansen eşbütünleşme analizi ile değişkenler arasında kaç bütünleşik vektör olduğu ve değişkenler arasında uzun dönemli bir ilişkinin olup olmadığı test edilmektedir. Bağımlı değişken ile bağımsız değişkenler ikili gruplar halinde analize dahil edilmiştir. Gecikme uzunlukları AIC kriterine göre hesaplanmıştır, test sonuçları $\% 5$ anlamlılık düzeyinde yorumlanmıştır. Analiz sonuçları aşağıda gösterildiği gibidir:

Tablo 7: Johansen Eşbütünleşme Testi Sonuçları

\begin{tabular}{|c|c|c|c|c|c|c|}
\hline \multirow[t]{2}{*}{ Değişkenler } & \multirow[t]{2}{*}{ Hipotez } & Maksimum & $\begin{array}{ll}\text { İz } & \text { Testi }\end{array}$ & \multicolumn{2}{|c|}{ Kritik Değer } & \multirow[t]{2}{*}{ Sonuç } \\
\hline & & $\begin{array}{l}\text { Öz Değer } \\
\text { Testi } \\
\text { Sonuçları }\end{array}$ & Sonuçları & \%5 (öz) & \%5 (öz) & \\
\hline $\begin{array}{l}\text { Kase- } \\
\text { enflasyon }\end{array}$ & $\begin{array}{l}H_{0}: r=0 \\
H_{1}: r \leq 1\end{array}$ & $\begin{array}{l}6.99408 \\
(0.6750)\end{array}$ & $\begin{array}{l}5.09874 \\
(0.6719)\end{array}$ & 15.76598 & 14.98760 & $\begin{array}{l}\mathrm{H}_{0} \\
\text { Kabul }\end{array}$ \\
\hline $\begin{array}{l}\text { Kase-petrol } \\
\text { fiyat1 }\end{array}$ & $\begin{array}{l}H_{0}: T=0 \\
H_{1}: r \leq 1\end{array}$ & $\begin{array}{l}19.75807 \\
(0.0001)\end{array}$ & $\begin{array}{l}18.97654 \\
(0.0000)\end{array}$ & 15.76598 & 14.98760 & $\mathrm{H}_{0}$ Red \\
\hline $\begin{array}{l}\text { Kase-sanayi } \\
\text { üretim } \\
\text { endeksi }\end{array}$ & $\begin{array}{l}H_{0}: T=0 \\
H_{1}: T \leq 1\end{array}$ & $\begin{array}{l}21.23056 \\
(0.0028)\end{array}$ & $\begin{array}{l}20.07984 \\
(0.0016)\end{array}$ & 15.76598 & 14.98760 & $\mathrm{H}_{0}$ Red \\
\hline $\begin{array}{l}\text { Kase-döviz } \\
\text { kuru }\end{array}$ & $\begin{array}{l}H_{0}: r=0 \\
H_{1}: r \leq 1\end{array}$ & $\begin{array}{l}9.09876 \\
(0.8901)\end{array}$ & $\begin{array}{l}7.980874 \\
(0.1789)\end{array}$ & 15.76598 & 14.98760 & $\begin{array}{l}\mathrm{H}_{0} \\
\text { Kabul }\end{array}$ \\
\hline Not: Gecikr & zunlukları & kriterine gör & olarak seçi & tir. & & \\
\hline
\end{tabular}

Johansen Eşbütünleşme testi sonuçları değerlendirilmesinde İz değer ve Maksimum Öz değer istatistiki değerlerinin kritik tablo değerlerinden büyük olması beklenmektedir. Tablo 7'de sonuçlar incelendiğinde İz değer ve Maksimum Öz değer istatistiğinin kritik değerlerden büyük olduğu görülmektedir. $\mathrm{Bu}$ sonuç seriler arasında eşbütünleşik vektör yoktur şeklinde kurulan $\mathrm{H}_{0}$ hipotezinin $\% 5$ anlamlılık düzeyinde reddedildiğini göstermiştir. Yani KASE değişkeni ile petrol fiyatı ve sanayi üretim endeksi değişkenleri arasında \%5 anlamlılık düzeyinde uzun dönemli bir ilişki söz konusudur. Diğer değişkenler ile KASE arasında herhangi bir uzun dönemli ilişkiye rastlanamamıştır.

Eşbütünleşmenin varlığı, iki değişken arasında en az bir yönde nedensellik olduğu anlamına gelmektedir (Gujarati, 2004: 696). Johansen eşbütünleşme testi sonuçlarına göre KASE ile uzun dönemli ilişkili çıkan petrol fiyatı ve sanayi üretim endeksi arasındaki ilişkinin yönünün belirlenmesi için nedensellik analizi 
yapılmıştır. Hata Düzeltme Modeline dayalı Granger nedensellik testi sonuçları Tablo 8'de sunulmuştur.

Tablo 8: Hata Düzeltme Modeline Dayalı Granger Nedensellik Testi Sonuçları

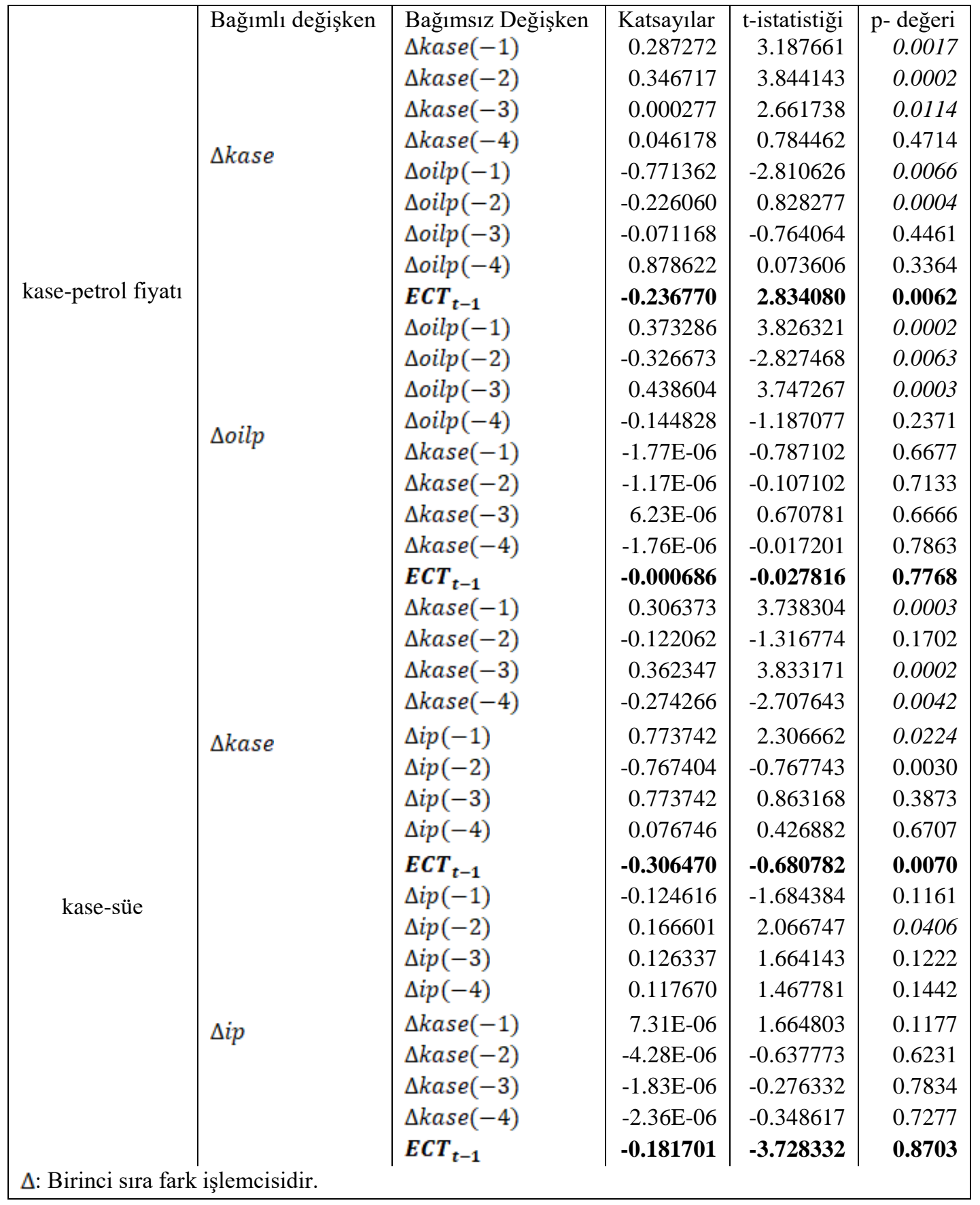


Kase ve petrol fiyatı serilerine uygulanan Hata düzeltme modeline dayalı Granger Nedensellik analiz sonuçları değerlendirildiğinde hata düzeltme parametresinin olasılık değeri anlamlı olup iki değişken arasında kısa dönemde de ilişki olduğunu göstermektedir. Hata düzeltme katsayısının -0.2369 olarak hesaplanması, bir şokun ilk ayda yaklaşık \%23 gibi bir hızla dengeye yaklaştı̆̆ının göstergesidir. Başka bir ifade ile 1 ay içerisinde sapmaların \%23'lük kısmının düzeldiği ve sistemin $1 / 0.23=4.34$ ay sonra dengeye geleceğini göstermektedir.

Kase ve sanayi üretim endeksi değişkenlerinin kısa dönemli ilişkisi incelendiğinde ise hata düzeltme parametresinin olasılık değerleri $\% 5$ 'den daha büyük olduğu için anlamsız olduğu görülmektedir. Değişkenler arasındaki nedensellik ilişkilerine bakıldığında; petrol fiyatları ve sanayi üretim endeksinden borsaya doğru tek yönlü nedensellik söz konusudur.

\section{Sonuç}

Başarılı bir yatırım stratejisini oluşturmak için hisse senedi fiyatlarını etkileyen faktörleri incelemek son derece önemlidir. Hisse senedi fiyatlarını etkileyen çok sayıda faktör bulunmaktadır. $\mathrm{Bu}$ faktörlerden bazılarında meydana gelen değişimler hisse senedi fiyatlarını yükseltirken bazılarındaki değişimler hisse senedi fiyatlarını düşürecektir. Yatırımcı bu değişimleri dikkate almadan yatırım stratejisini oluşturduğu zaman vereceği yatırım kararlarında hata yapabilmektedir. Dolayısıyla hisse senedini etkileyen faktörleri araştıran çok sayıda ampirik çalışma yapılmıştır ve yapılmaya devam etmektedir. Söz konusu çalışmalar tek bir ülke veya ülke gruplarını kapsamakta olup, farklı yöntemlerle analiz edilmiştir. Kazakistan borsasını konu alan çalışmalar yok denecek kadar az sayıdadır. Bu çalışmada hisse senedini etkileyen faktörlerin Kazakistan borsası için yapılması literatüre katkı sağlayacaktır.

Çalışmada hisse senedini etkileyen makroekonomik faktörler araştırılmış olup, değişkenler arasındaki ilişkilerin incelenmesi için EKK yöntemi, Eşbütünleşme ve hata düzeltme modeline dayalı nedensellik analizi yapılmıştır. Analize başlamadan önce birim kök testleri yapılmıştır. Birim kök testi sonucunda faiz oranı hariç diğer değişkenlerin 1.dereceden durağan oldukları görülmüştür.

EKK analizi sonuçlarına göre faiz oranı, sanayi üretim endeksi, döviz kuru, TÜFE ve petrol fiyatları değişkenlerinde meydana gelen değişimler Kazakistan borsasını \%62 oranında açıklamaktadır. Bunun anlamı bağımsız değişkenlerde meydana gelen değişimler bağımlı değişkeni yaklaşık olarak \%62 oranında açıklamaktadır. Modele dahil edilen bağımsız değişkenlerden petrol fiyatı ve döviz kuru değişkenleri istatistiki olarak anlamlı olup, borsayı negatif etkilemektedir. Döviz kurunda meydana gelen \%1'lik artış borsayı \%1.72 oranında azaltırken, petrol fiyatlarındaki \%1'lik artış \%1.14 oranında düşürmektedir. 
Eşbütünleşme analizi sonuçlarına göre ise KASE değişkeni ile petrol fiyatı ve sanayi üretim endeksi değişkenleri $\% 5$ anlamlılık düzeyinde eşbütünleşik çıkmıştır. Diğer değişkenler ile KASE arasında herhangi bir uzun dönemli ilişkiye rastlanamamıştır.

Hata düzeltme modeline dayalı nedensellik analizi sonuçlarına bakıldığında petrol fiyatları ve sanayi üretim endeksinden borsaya doğru tek yönlü nedensellik söz konusudur.

Makroekonomik değişkenlerin hisse senedi fiyatları üzerindeki etkisine verilen ilgiye rağmen konuyu hisse senedi piyasasında işlem gören firmaların ait oldukları sektörler itibariyle ele alan sınırlı sayıda çalışma söz konusudur. Çeşitli sektörlerin makroekonomik değişkenlerden farklı mekanizmalar üzerinden etkilendiği dikkate alınırsa söz konusu değişkenler karşısında sektörlerin homojen olmayan tepkilerini ortaya koymak portföy risk yönetimi açısından son derece önemlidir. Dolayısıyla ileride yapılacak çalışmaların makroekonomik değişkenlerin hisse senedi piyasasına etkisinin sektörel analizinin yapılması literatüre katkı sağlayacaktır.

\section{Kaynakça}

Abdullah, D. A., \& Hayworth, S. C. (1993). Macroeconometrics of stock price fluctuations. Quarterly Journal of Business and Economics, 50-67.

Adrangi, B., Chatrath, A., Pamplin, R. B., \& Sanvicente, A. Z. (2002). Inflation, output, and stock prices: Evidence from Brazil. Journal of Applied Business Research, 18(1), 61-76.

Aggarwal, R., Inclan, C., \& Leal, R. (1999). Volatility in emerging stock markets. Journal of Financial and Quantitative Analysis, 34(1), 33-55.

Agrawalla, R. K., \& Tuteja, S. K. (2008). Share Prices and Macroeconomic Variables in India. Journal of Management Research (09725814), 8(3).

Aktaş, M., \& Akdağ, S. (2013). Türkiye'de ekonomik faktörlerin hisse senedi fiyatlari ile ilişkilerinin araştirilmasi. International Journal of Social Science Research, 2(1), 50-67.

Albayrak, A. S., Öztürk, N., \& Tüylüoğlu, Ş. (2012). Makroekonomik Değişkenler İle Sermaye Hareketlerinin İmkb-100 Endeksi Üzerindeki Etkisinin İncelenmesi. International Journal of Economic \& Social Research, 8(2). 
Al-Jafari, M. K., Salameh, R. M., \& Habbash, M. R. (2011). Investigating the relationship between stock market returns and macroeconomic variables: evidence from developed and emerging markets. International Research Journal of Finance and Economics, 79, 6-30.

Asprem, M. (1989). Stock prices, asset portfolios and macroeconomic variables in ten European countries. Journal of Banking \& Finance, 13(4-5), 589-612.

Barrows, C. W., \& Naka, A. (1994). Use of macroeconomic variables to evaluate selected hospitality stock returns in the US. International Journal of Hospitality Management, 13(2), 119-128.

Bekaert, G., \& Harvey, C. R. (1997). Emerging equity market volatility. Journal of Financial economics, 43(1), 29-77.

Bhattacharya, B., \& Mukherjee, J. (2002). The nature of the causal relationship between stock market and macroeconomic aggregates in India: An empirical analysis. In 4th annual conference on 349xcha and finance, Mumbai (pp. 401-426).

Bilson, C. M., Brailsford, T. J., \& Hooper, V. J. (2001). Selecting macroeconomic variables as explanatory factors of emerging stock market returns. PacificBasin Finance Journal, 9(4), 401-426.

Büyüksalvarci, A., \& Abdioglu, H. (2010). The causal relationship between stock prices and macroeconomic variables: A case study for Turkey. International Journal of Economic Perspectives, 4(4), 601.

Caşkurlu, S. İ. (2001). Kısa Vadeli Sermaye Hareketlerinin Gelişmekte Olan Ülkelere Etkileri ya da Modern Bir Kırmızı Başlıklı Kı. Mülkiye Dergisi, 25(229), 163-184.

Celov, D., \& Grigaliuniene, Ž. (2013). Economic forces, sentiment and emerging Eastern European stock markets. Research in Economics and Business: Central and Eastern Europe, 2(2).

Chen, N. F., Roll, R., \& Ross, S. A. (1986). Economic forces and the stock market. Journal of business, 383-403.

Çelik, İ. (2011). Vadeli işlem piyasasında fiyat keşfi: 349xcha vadeli işlem ve opsiyon borsasında ampirik bir uygulama (Doktora Tezi, SDÜ Sosyal Bilimler Enstitüsü).

Das, A. (2017). An Association of Macroeconomic Variables and Stock Index, India: An Empirical Evidence. MERC Global's International Journal of Management, 5(1), 1-7.

Diacogiamnis, G. P., Tsiritakis, E. D., \& Manolas, G. A. (2001). Macroeconomic factors and stock returns in a changing economic framework: The case of the Athens stock 349xchange. Managerial finance, 27(6), 23-41. 
Dickey, D. A. ve Fuller, W. A. (1979). Distribution of the Estimators for Autoregressive Time Series with a Unit Root. Journal of the American Statistical Association, 74(366a), 427-431.

Fama, E. F. (1981). Stock returns, real activity, inflation, and 350xcha. The American economic review, 71(4), 545-565.

Filis, G. (2010). Macro economy, stock market and oil prices: Do meaningful relationships exist among their cyclical fluctuations?. Energy Economics, 32(4), 877-886.

Gay, R. D. (2016). Effect of macroeconomic variables on stock market returns for four emerging economies: Brazil, Russia, India, and China. The International Business \& Economics Research Journal (Online), 15(3), 119.

Geske, R., \& Roll, R. (1983). The fiscal and monetary linkage between stock returns and inflation. The journal of Finance, 38(1), 1-33.

Gong, F., \& Mariano, R. S. (1997). Stock market returns and economic 350xchange350als in an emerging market: the case of Korea. Financial Engineering and the Japanese Markets, 4(2), 147-169.

Gujarati, D. N., Porter, D. C., Şenesen, Ü., \& Günlük-Şenesen, G. (2012). Temel ekonometri. Literatür Yayıncılık.

Güngör, B., \& Kaygın, C. Y. (2015). Dinamik panel veri analizi ile hisse senedi fiyatini etkileyen faktörlerin belirlenmesi. Kafkas Üniversitesi Iktisadi ve İdari Bilimler Fakültesi Dergisi, 6(9).

Humpe, A., \& Macmillan, P. (2009). Can macroeconomic variables explain longterm stock market movements? A comparison of the US and Japan. Applied Financial Economics, 19(2), 111-119.

Ibrahim, M. (1999). Macroeconomic variables and stock prices in Malaysia: An empirical analysis. Asian Economic Journal, 13(2), 219-231.

Ibrahim, M. H., \& Aziz, H. (2003). Macroeconomic variables and the Malaysian equity market: A view through 350xchang subsamples. Journal of economic studies, 30(1), 6-27.

IFS. (2018). International Financial Statistics, http://data.imf.org/

Issahaku, H., Ustarz, Y., \& Domanban, P. B. (2013). Macroeconomic Variables and Stock Market Returns in Ghana: Any Causal Link?. Asian Economic and Social Society, 3(8)

Kandir, S. Y. (2008). Macroeconomic variables, firm characteristics and stock returns: Evidence from Turkey. International research journal of finance and economics, 16(1), 35-45. 
Kazakistan Ulusal Bankası, (2018). Dıș borç istatistikleri, URL: http://www.nationalbank.kz/?docid=285\&switch=kazakh Erișim: $\underline{25.05 .2018}$

Kwon, C. S., \& Shin, T. S. (1999). Cointegration and causality between macroeconomic variables and stock market returns. Global Finance Journal, 10(1), 71-81.

Kwon, C. S., Shin, T. S., \& Bacon, F. W. (1997). The effect of macroeconomic variables on stock market returns in developing markets. Multinational Business Review, 5(2), 63.

Le, T. H., \& Chang, Y. (2011). The impact of oil price fluctuations on stock markets in developed and emerging economies.

Lee, J. W., \& Brahmasrene, T. (2018). An Exploration of Dynamical Relationships between Macroeconomic Variables and Stock Prices in Korea. The Journal of Asian Finance, Economics and Business (JAFEB), 5(3), 7-17.

Maysami, R. C., \& Koh, T. S. (2000). A vector error correction model of the Singapore stock market. International Review of Economics \& Finance, 9(1), 79-96.

Mookerjee, R., \& Yu, Q. (1997). Macroeconomic variables and stock prices in a small open economy: The case of Singapore. Pacific-Basin Finance Journal, 5(3), 377-388.

Mukherjee, T. K., \& Naka, A. (1995). Dynamic relations between macroeconomic variables and the Japanese stock market: an application of a vector error correction model. Journal of Financial Research, 18(2), 223-237.

Muradoglu, G., Taskin, F., \& Bigan, I. (2000). Causality between stock returns and macroeconomic variables in emerging markets. Russian \& East European Finance and Trade, 36(6), 33-53.

Nasseh, A., \& Strauss, J. (2000). Stock prices and domestic and international macroeconomic activity: a cointegration approach. The Quarterly Review of Economics and Finance, 40(2), 229-245.

Ndlovu, B., Faisa, F., Resatoglu, N. G., \& Türsoy, T. (2018). The Impact Macroeconomic Variables on Stock Returns: A Case of the Johannesburg Stock Exchange. Romanian Statistical Review, (2).

Omran, M., \& Pointon, J. (2001). Does the inflation rate affect the performance of the stock market? The case of Egypt. Emerging Markets Review, 2(3), 263279. 
Özer, A., Kaya, A., \& Özer, N. (2011). Hisse Senedi Fiyatları İle Makroekonomik Değişkenlerin Etkileşimi. Dokuz Eylül Üniversitesi İktisadi ve İdari Bilimler Fakültesi Dergisi, 26(1).

Park, J., \& Ratti, R. A. (2008). Oil price shocks and stock markets in the US and 13 European countries. Energy economics, 30(5), 2587-2608.

Patra, T., \& Poshakwale, S. (2006). Economic variables and stock market returns: evidence from the Athens stock 352xchange. Applied Financial Economics, 16(13), 993-1005.

Pearce, D. K., \& Roley, V. V. (1988). Firm characteristics, unanticipated inflation, and stock returns. The Journal of Finance, 43(4), 965-981.

Ratanapakorn, O., \& Sharma, S. C. (2007). Dynamic analysis between the US stock returns and the macroeconomic variables. Applied Financial Economics, 17(5), 369-377.

Sadorsky, P. (1999). Oil price shocks and stock market activity. Energy economics, 21(5), 449-469.

Singh, D. (2010). Causal Relationship Between Macro-Economic Variables and Stock Market: A Case Study for India. Pakistan Journal of Social Sciences (PJSS), 30(2).

Syzdykova, A. (2018). Petrol fiyatlarının BRIC ülkelerinin borsalarına etkisi. Uluslararası Ekonomi, İsletme ve Politika Dergisi, 2(1), 1-20.

Syzdykova, A.(2017). Petrol fiyatlarının hisse senedi piyasasına etkisi: Kazakistan borsas1 örneği. Finans Ekonomi ve Sosyal Araştırmalar Dergisi (FESA), 2(4), 259-269.

Tar1, R. (2008). Ekonometri (5. Bask1). Kocaeli Üniversitesi Yayın, (172).

Thornton, J. (1993). Money, output and stock prices in the UK: Evidence on some (non) relationships. Applied Financial Economics, 3(4), 335-338.

Togay, S. (2009). Kazakistan Ekonomisinin Petrole Bağımlılığının Azaltılmasında Para Politikasının Rolü. Bilig, Türk Dünyası Sosyal Bilimler Dergisi, 48, 208-240.

Üçdoğruk, Ș. (1996). Türkiye'de Sağlık Harcamalarının Ekonometrik Analizi: Eşbütünleşme Testi. Ekonomik Yaklasim, 7(21), 101-112.

WFE.(2018). World Federation of Exchange, https://www.worldexchanges.org/home/ Erişim: 22.05.2018

Yalçın, Y. (2015). Petrol fiyatı şoklarının BDT borsaları üzerine etkisi: Rusya, Kazakistan Ve Ukrayna. İktisadi ve İdari Bilimler Fakültesi Dergisi, 17(1), 64-81.

Yavuz, N. Ç. (2015). Finansal ekonometri. Der Yayınları, Istanbul. 


\section{Macroeconomic Variables and Equity Market Relation: KASE example}

\section{Extended Abstract}

\section{Introduction}

Stock shares are a very important investment tool for investors and stock values are affected by various factors. Investors constantly develop investment strategies to achieve high incomes. To this end, they closely follow these factors in order to estimate stock value movements. Also, researchers are following the factors affecting stock values and trying to explain their effects by building various models.

Empirical studies which examined the relationship between stock values and macroeconomic factors used many variables. Among the modelled variables, there are variables representing money market (money supply, interest rate), variables representing commodity market (industrial production, GDP, unemployment rate, inflation rate, CPI, balance of foreign trade, import-export, consumption volume), global variables (exchange rate, oil price, MSCI World Index, S\&P 500 Index) and other variables (budget deficit, direct foreign investments, portfolio investments). Studies showed that macroeconomic indicators affecting stock values vary from country to country.

In the literature, there are many empirical studies studying the relationship between stock returns and macroeconomic variables. But there is almost no study on this relationship in the Kazakhstan Stock Exchange (KASE) ${ }^{* *}$. Therefore, this study will contribute to the literature.

\section{Data Set and Method}

In this study, KASE closing prices are used as the dependent variable. Independent variables are basic national macroeconomic indicators, namely inflation rate, interest rate, exchange rate, and industrial production index. However, Kazakhstan is a very important oil producer and exporter. Therefore, we included the oil price in the model. We used the monthly data from June 2000 to April $2017^{\dagger \dagger}$.

Following model is used in this study:

$\operatorname{lnkase}_{t}=\beta_{0}+\beta_{1} \operatorname{lnip}_{t}+\beta_{2} i_{t}+\beta_{3} \operatorname{lner}_{t}+\beta_{4} \operatorname{lncpi}_{t}+\beta_{5} \operatorname{lnoilp}_{t}+u_{t}$

Terms in the model correspond respectively; kase- dependent variable, stock exchange closing price, ip- industrial production index, ir- interest rate, er- exchange rate, inf- CPI, and oilp- oil price. The term $\ln$ represents the natural logarithm of variables, and term $u_{t}$ represents the stochastic error.

We performed time series analysis and used Eviews 8 econometric package program.

We used the OLS method to determine the statistical relationship between variables, Johansen cointegration test to determine the long-term relationship, and Granger causality analysis to determine the directionality of these relationships.

\section{Results}

Data which is going to be used in the time series analysis should first be tested for their stability feature. In this context, we performed an ADF unit square test in order to determine the stability of variables. Results showed that all variables except interest rate have a stability at the first order.

** Kazakhstan Stock Exchange (KASE) was opened on November 17, 1993.

${ }^{\dagger}$ We used this time period because oldest records we could obtain was from June 2000. Index data was obtained from Bloomberg database. 
According to the results of statistical tests from OLS estimation model, F statistics expressing the significance of the model is less than $5 \%$ and the model is statistically significant. $\mathrm{R}^{2}$ value is $62 \%$. This means that the changes in independent variables explains the $62 \%$ of the changes in the dependent variables.

Of independent variables included in the model, oil price and exchange rate are statistically significant and effect stock exchange negatively. A $1 \%$ increase in exchange rate decreases stock exchange value by $1.72 \%$, whereas a $1 \%$ increase in oil price decreases stock exchange value by petrol by $1.14 \%$. Since the significance of the other variables is less than $5 \%, \mathrm{H}_{0}$ is not refuted; therefore, the listed variables fail to statistically explain the changes in the stock exchange.

We tried to estimate the number of vectors between the variables using Johansen cointegration analysis. We also tested whether these relations are long-term or short-term relations. We analyzed variables with dependent-independent variable pairs. Results showed a long-term relationship between KASE variable, and oil price and industrial production index at 5\% significance level. We failed to find any long-term relationship between the other variables and KASE variable.

When the results of Granger Causality analysis based on the error correction model performed using the KASE and oil price variables are evaluated, we see that the probability value of error correction parameter is statistically significant and there is also a short-term relationship between these two parameters. An error correction coefficient with a value of -0.2369 indicates that a shock is quickly rebalanced in the first month with a speed of $23 \%$. In other words, $23 \%$ of the deviation is recovered in 1 month and the system is rebalanced in 4.34 months (1/0.23).

When the short-term relationship between KASE and industrial production index variables is evaluated, we see that this relationship is not significant as the probability valued of error correction parameter is bigger than 5\%. When we look at the causality relations between variables; we see a unidirectional causality from oil prices and industrial production index to stock market value.

\section{Conclusion}

In order to design a successful investment strategy, it is very important to examine the factors affecting the stock prices. And there are many factors affecting the stock prices. Some of those affect stock prices positively, whereas some affect them negatively. If an investor does not take these factors into account, then he/she may make mistakes. Therefore, many studies were done to examine these factors.

This study examined the effect of macroeconomic factors (interest rate, industrial production index, exchange rate, CPI and oil price) on the Kazakhstan Stock Exchange. This study is important as it examines a developing market. According to the results of the OLS analysis, a change in the study variables accounts $62 \%$ change in the Kazakhstan stock exchange.

The relationship between KASE variable and oil price and industrial production index variables has a 5\% significance level and is a long-term relationship. In addition, we found a unidirectional causality from oil price and industrial production index variables to the stock exchange value. This result shows that investors should take oil price and industrial production index into account while designing their investment strategies. Future studies may consider analyzing the relationship between these variables using the refraction test. Besides, future studies may consider studying the effect of macroeconomic variables on various sectoral indexes. 